\title{
Caracterização da fauna parasitária do Pseudalopex gymnocercus (graxaim-do-campo) e do Cerdocyon thous (graxaim-do-mato) na região sul do Rio Grande do Sul*
}

\author{
JERÔNIMO LOPES RUAS
}

\author{
João Guilherme Werner Brum (Orientador - UFRGS)
}

Banca: Carlos Marcos Barcellos de Oliveira (UFRGS), Elvia Elena Vianna (UCPel), Nara Amélia da Rosa Farias (UFPel).

Com o objetivo de estudar a fauna parasitária de Cerdocyon thous e Pseudalopex gymnocercus foram estimadas a prevalência, a intensidade média de infecção e abundância de helmintos gastrintestinais e artrópodes nesses hospedeiros. Foram capturados 40 canídeos silvestres na Região Sul do Estado do Rio Grande do Sul, nos municípios de Pedro Osório e Pelotas. Os animais foram capturados usando-se armadilha tipo Live Trap. Logo após a captura, os animais eram sedados, momento em que se coletava sangue e buscava-se coletar artrópodes ectoparasitos mediante exame minucioso. Em seguida os animais eram transportados para o Laboratório de Parasitologia do Departamento de Microbiologia e Parasitologia do Instituto de Biologia da UFPel, onde eram sacrificados usando-se pentobarbital sódico. Após a necropsia, os compartimentos do trato digestório, respiratório e renal foram isolados e examinados na busca de parasitos. O crânio dos animais foi usado para identificação taxonômica dos canídeos, dos quais $45 \%$ eram C. thous e 55\% P. gymnocercus, podendo-se inferir que ambos canídeos são encontrados habitando a região fisiográfica desse trabalho. A totalidade dos animais (100\%) apresentou-se parasitado. Amblyomma aureolatum é o carrapato com maior prevalência em P. gymnocercus $(23,7 \%)$ e $C$. thous $(61,11 \%)$ na região sul do Rio Grande do Sul. Nos nematódeos, os parasitos mais freqüentes foram: Ancylostoma caninum (C. thous 22,22\%e P. gymnocercus 45,45\%), Molineus felineus (C. thous 5,56\% e P. gymnocercus 9,90\%), Strongyloides spp. (C. thous 16,67\% e P. gymnocercus 22,73\%), Trichuris spp (C. thous 11,11\% e P. gymnocercus 13,64\%), e Capillaria hepática (C. thous 5,56\% e P. gymnocercus 13,64\%). Nos trematódeos, os parasitos encontrados foram: Alaria alata (C. thous 50,00\% e P. gymnocercus 36,36\%) e Athesmia heterolecithodes (C. thous 5,56\%). Nos cestódeos, os parasitos encontrados foram: Spirometra spp (C. thous $61,11 \%$ e $P$. gymnocercus $54,55 \%$ ) e Diphillobotriidae (C. thous 77,78\% e P. gymnocercus $81,82 \%$ ). Nos Acanthocephala os parasitos encontrados foram: Centrorhynchus sp. (C. thous 5,56\%). Nos protozoários, os parasitos encontrados foram: Babesia spp ( $P$. gymnocercus $13,64 \%$ ), diagnosticada por exame direto.

Descritores: Cerdocyon thous, Pseudalopex gymnocercus, helmintos, ectoparasitos, Babesia spp.

Apresentada: 30 março 2005

${ }^{*}$ Tese de Doutorado n. 59 (Especialidade: Parasitologia). 61f. Programa de Pós-graduação em Ciências Veterinárias [www.ufrgs.br/ppgcv], Faculdade de Veterinária, Universidade Federal do Rio Grande do Sul (UFRGS), Porto Alegre, RS/Brasil. CORRESPONDÊNCIA: J.L. Ruas [ruas@ufpel.tche.br]. 


\title{
Parasites of pampas fox (Pseudalopex gymnocercus) and crab-eating-fox (Cerdocyon thous) in Rio Grande do Sul State, Southern Brazil ${ }^{* *}$
}

\author{
JERÔNIMO LOPES RUAS
}

João Guilherme Werner Brum (Orientador - UFRGS)

Committee: Carlos Marcos Barcellos de Oliveira (UFRGS), Elvia Elena Vianna (UCPel), Nara Amélia da Rosa Farias (UFPel).

With the objective of studying parasitic fauna of Cerdocyon thous and Pseudalopex gymnocercus the prevalence, mean intensity of infection and abundance of gastrintestinal helminths and arthropods were observed in those hosts. 40 wild canids were captured in the South Area of the State of Rio Grande do Sul, in the counties of Pedro Osório and Pelotas. The animals were captured being used trap type "Live Trap". Therefore after the capture, the animals were anesthesied and in that moment, the blood was collected and the presence or not of ectoparasites was observed. Therefore the animals were transported for the Laboratory of Parasitology, Department of Microbiology and Parasitology, Institute of Biology, UFPel, where they were sacrificed being used sodic pentobarbitol. After this, the portions of the intestinal and respiratory tract and kidney were isolated and examined in the search of parasites. The skull of the animals was used for the taxonomic identification of the hosts. $C$. thous (45\%) and P. gymnocercus (55\%) where observed. All hosts (100\%) were parazited by some parasite type. Two species of Amblyomma were identified: A. aureolatum and A. tigrinum. Among the nematoda, the most frequent parasites were: Ancylostoma caninum (C. thous 22,22\%e P. gymnocercus 45,45\%), Molineus felineus (C. thous 5,56\% e P. gymnocercus 9,90\%), Strongyloides spp. (C. thous 16,67\% e P. gymnocercus 22,73\%), Trichuris spp (C. thous 11,11\% and P. gymnocercus 13,64\%), and Capillaria hepática (C. thous 5,56\% and P. gymnocercus 13,64\%). Among the trematoda, were found Alaria alata (C. thous 50,00\% and P. gymnocercus 36,36\%) and Athesmia heterolecithodes (C. thous 5,56\%). Among the cestoda, the found parasites were: Spirometra spp. and Diphillobotriidae. Acanthocephala the found parasites were: Centrorhynchus sp. and among the protozoa, the found parasites were: Babesia spp (P. gymnocercus 13,64\%), diagnosed by direct exam.

Key words: Cerdocyon thous, Pseudalopex gymnocercus, helminths, ectoparasites, Babesia spp. 